JURNAL ILMIAH KOMPUTER GRAFIS, Vol.13, No.2, Juli 2020, pp. 1 - 6

p-ISSN : 1979-0414(print)

e-ISSN : 2621-6256 (online)

http://journal.stekom.ac.id/index.php/pixel

- page 1

\title{
Penggunaan Naratif Dalam Video Game Sebagai Media Edukasi Isu Dunia: Studi Kasus Detroit Become Human
}

\section{Use of Narrative in Video Games as Educational Media World Issue: Case Study Detroit Become Human}

\author{
Tony Wibowo ${ }^{1)}$, Kelfia Limanda $\left.{ }^{*}, 2\right)$ \\ ${ }^{1)}$ Program Studi Sistem Informasi, Universitas Internasional Batam \\ Sei Ladi, Jl. Gajah Mada, Baloi Permai, Kec. Sekupang, Kota Batam, Kepulauan Riau 29442 \\ 2) Program Studi Sistem Informasi, Universitas Internasional Batam \\ Sei Ladi, Jl. Gajah Mada, Baloi Permai, Kec. Sekupang, Kota Batam, Kepulauan Riau 29442
}

\begin{abstract}
Abstrak - Video game dengan narasi kuat semakin popular pada kalangan game developer. Terdapat sejumlah game yang dikembangkan dengan isu dunia dalam naratifnya. Penelitian ini dilakukan untuk membuktikan apakah video game berpotensi sebagai media edukasi terhadap permasalahan dunia. Penelitian ini dilakukan dengan mengekspos video game melalui game play dari video game Detroit Become Human kepada 27 responden yang belum familier dengan video game tersebut selama 22 hari dan mengumpulkan laporan mereka mengenai pengalaman mereka melalui kuesioner online. Penelitian diuji dengan melakukan perbandingan terhadap pandangan responden mengenai permasalahan dunia tersebut sebelum dan sesudah responden terekspos oleh video serta melakukan kodifikasi yang dengan maksud untuk mengkuantifikasi respon yang diterima. Hasil penelitian membuktikan bahwa konsensus setuju bahwa video game berpotensi untuk menjadi media edukasi terhadap permasalahan dunia. Selain daripada itu juga ditemukan bahwa video game mampu mengedukasi pemain dalam jangka panjang namun tidak signifikan dalam edukasi jangka pendek.
\end{abstract}

Kata kunci - video game; edukasi; SDG, isu dunia

Abstract - Video games with strong narratives are getting popularity among video game developers. There are a number of games that were developed with world issues as the narrative. This research was conducted to prove whether a video games have a potential to be a media for education on world issues. This research was conducted by exposing video games through game play video of Detroit Become Human video game to 27 respondents who are not familiar with said video game for 22 days and submit their report about their experience through online questionnaire. The study was tested by comparing the respondents' views on the world's issues before and after the respondents exposed to the video and codifying their responses in order to quantify the responses received. The results of the study prove that the consensus agrees that video games have the potential to be a media for education on world issues. Apart from that, it was also found that video games were able to educate players in the long term but not significant in the short term.

Key words - video game; education; SDG, world issue

\section{Pendahuluan}

Sustainable Development Goals (SDG) terbentuk dengan adanya persetujuan dari Perserikatan BangsaBangsa (PBB) pada bulan September tahun 2015 yang lalu dengan 17 tujuan dan 169 target dimana SDG dibentuk untuk mengintegrasi permasalahan yang berhubungan dengan keberlanjutan pembangunan dengan hal yang berkaitan dengan ekonomi, lingkungan dan sosial dalam sebuah negara [1]. Pentingnya SDG adalah karena SDG memiliki tujuan untuk menyeimbangkan kemajuan ekonomi, perlindungan lingkungan dengan tidak melupakan perhatian terhadap kepentingan sosial yang merupakan faktor fundamental untuk kehidupan yang sehat dan sejahtera hal ini merupakan alasan mengapa agenda 2030 dari SDG sangat ditekankan dengan hak asasi manusia [2]. Ketujuh belas tujuan dari SDG didasari oleh ekonomi, lingkungan dan juga sosial yang mana isu mengenai rasisme juga termasuk kedalamnya.

Banyak media yang dapat digunakan untuk mengedukasi masyarakat mengenai SDG, salah satunya adalah melalui video game. Terdapat beberapa video games yang menceritakan tentang konten dari SDG. Video game adalah salah satu media yang bersifat interaktif, imersif dan secara aktif dapat melibatkan pemainnya [3]. Interaktif sendiri merupakan kata yang berasal dari Bahasa 
JURNAL ILMIAH KOMPUTER GRAFIS, Vol.13, No.2, Juli 2020, pp. 1 - 6

p-ISSN : 1979-0414(print) e-ISSN : 2621-6256 (online)

http://journal.stekom.ac.id/index.php/pixel

inggris yang memiliki arti suatu kegiatan atau masalah dalam bentuk interaksi, debat, dalam proses berpikir yang berarti untuk menyelesaikan bersama [4]. Salah satu jenis video games yang dapat digunakan sebagai media edukasi tentang SDG adalah serious games. Serious game adalah game yang mengacu pada game digital yang dirancang dengan tujuan utama sebagai media pembelajaran dan tidak berfokus pada hiburan, sebagai contoh terdapat beberapa permainan representatif yang terkait dengan SDG [5].

Terdapat beberapa contoh Serious game yang membahas tentang tujuan yang ada dalam SDG misalnya pada game Beyond: Two Souls yang mana pada game ini yang mana terdapat beberapa narasi yang menceritakan tentang kemiskinan seperti ketika Jodie, pemeran utama dalam game ini berteman dan berhasil menyelamatkan sekelompok tuna wisma dari bangunan yang terbakar bahkan juga membantu salah satu dari mereka untuk melahirkan [6]. Pada game lain yang juga menyinggung mengenai tujuan SDG adalah game Fallout yang mana menunjukkan keadaan krisis clean energy setelah terjadinya penjatuhan bom nuklir, dengan kejadian itu tentunya menyebabkan krisis clean energy [7].

Contoh lain adalah penelitian mengenai serious game yang mengangkat tema mengenai perubahan iklim yang merupakan salah satu tujuan dari SDG yang menyatakan bahwa kemajuan minat pendidikan terkait dengan perubahan iklim dapat tercermin dari semakin meningkatnya serious game yang berhubungan dengan iklim yang akhir-akhir ini juga memasukkan games yang berfokus pada adaptasi iklim [8]. Penelitian lainnya yang membahas mengenai potensi game Minecraft untuk perancangan kota untuk anak anak yang mana hal ini dapat dikaitkan juga dengan tujuan SDG yang ke 9 yaitu mengenai pembangunan infrastruktur [9].

Dalam video game juga terdapat media yang dapat membangun interaksi pemain dengan game yang sedang dimainkan salah satunya yaitu dengan narasi yang bersifat interaktif. Setiap video game memiliki narasi, namun terdapat dua bentuk akhir dari video game naratif yaitu narasi linier dan narasi bercabang. Narasi bercabang memberikan kebebasan kepada pemain untuk menentukan perubahan pada cerita, narasi bercabang ini tidak hanya melakukan interaksi kepada pemain tetapi juga mencerminkan dilema moral terhadap pemainnya. Detroit Become Human adalah salah satu contoh video game dengan akhir narasi yang bercabang [10]. Salah satu studi mengenai keputusan moral dalam video game Detroit Become Human, popularitas video game dengan dilema moral terkait dengan keputusan yang berhubungan dengan moral sudah semakin meningkat. Detroit Become Human adalah salah satu video game bergenre naratif dengan dilema moral berbasis narasi yang menyuguhkan berbagai kasus seperti rasisme, diskriminasi, LGBT, demokrasi, hubungan antar sesama dan masalah lainnya yang menawarkan berbagai macam keputusan moral kepada pemain, masing-masing pilihan diikuti dengan konsekuensi skala besar yang menghasilkan pohon narasi yang sangat bercabang [11]

Perkembangan game di Indonesia yang cukup popular menjadikan game menjadi bagian dari kehidupan masyarakat modern baik anak-anak hingga dewasa dan sejak tahun 2011, pemain game di Indonesia telah mencapai angka sekitar 6.5 juta pemain [12]. Berdasarkan penelitian terdahulu yang memilih Batam sebagai target untuk melakukan penelitian mengenai Pengaruh Game Berbasis Coding Terhadap Keberlanjutan Minat Belajar Programming Siswa dikarenakan secara geografis Batam adalah kota yang sangat dekat dengan negara Malaysia dan juga Singapura yang mana dengan hal ini membuat akses permainan atau game dan juga hiburan elektronik di Batam sangat bervariasi [13].

Penelitian ini dilakukan dengan didasari oleh penelitian yang telah dilakukan oleh peneliti terdahulu. Penelitian lainnya yang melakukan studi mengenai potensi video games sebagai media belajar untuk moral yang membuktikan bahwa video game berpotensi cukup baik sebagai media pembelajaran moral [14]. Juga terdapat studi yang telah membuktikan bahwa tindakan yang direncanakan dengan tujuan untuk menolong orang lain tanpa memperhatikan maksud dari penolong di dalam game dapat meningkatkan kebiasaan yang sama dalam kehidupan nyata [15]. Selain daripada itu, penelitian yang telah dilakukan sebelumnya juga dapat membuktikan bahwa komponen dalam video game terutama dalam video game berunsur naratif dapat mendorong kesensitifan moral pemainnya meskipun dalam kondisi terkendali [16]. Dan Dimana hasil penelitian tersebut menunjang hasil penelitian yang juga telah dilakukan dengan menggunakan metode self-reporting yang menyimpulkan bahwa tindakan yang dipilih saat bermain video game juga mencerminkan tindakan dan pola pikir pemain dalam menjalankan kehidupan nyatanya [17]. Penelitian bertujuan untuk mengkonfirmasi kemampuan media video game untuk menyampaikan isu serius seperti pada SDG. 
JURNAL ILMIAH KOMPUTER GRAFIS, Vol.13, No.2, Juli 2020, pp. 1 - 6

p-ISSN : 1979-0414(print) e-ISSN : 2621-6256 (online)

http://journal.stekom.ac.id/index.php/pixel

\section{Metode Penelitian}

Penelitian ini merupakan penelitian yang dibantu oleh 27 responden dari kalangan Mahasiswa dan juga Professional Muda dengan rentang usia 18-25 tahun dimana responden yang terpilih mendefinisikan dirinya sebagai bukan gamer atau gamer casual. Target responden yang terpilih sangat sesuai dengan penelitian yang akan dilakukan ini dikarenakan responden belum terekspos oleh video game, terutama dengan jenis game serius dengan naratif yang kuat seperti pada game Detroit Become Human.

Penelitian ini merupakan penelitian yang

Tabel 1. Daftar pertanyaan kuesioner terkait permasalahan dunia

\begin{tabular}{cl}
\hline No & \multicolumn{1}{c}{ Pertanyaan } \\
\hline 1 & $\begin{array}{l}\text { Menurut anda, Isu 'Rasisme' perlu seberapa cepa } \\
\text { ditangani }\end{array}$ \\
\hline 2 & $\begin{array}{l}\text { Menurut anda, Isu 'Kekerasan Pada Anak' perlu } \\
\text { seberapa cepat ditangani }\end{array}$ \\
\hline 3 & $\begin{array}{l}\text { Menurut anda, Isu 'Bullying' perlu seberapa } \\
\text { cepat ditangani }\end{array}$ \\
\hline 4 & $\begin{array}{l}\text { Menurut anda, Isu 'Kesehatan Mental' perlu } \\
\text { seberapa cepat ditangani }\end{array}$ \\
\hline 5 & $\begin{array}{l}\text { Menurut anda, Isu 'Kesenjangan Socio-Ekonomi } \\
\text { perlu seberapa cepat ditangani }\end{array}$ \\
\hline 6 & $\begin{array}{l}\text { Menurut anda, Isu 'Drugs Abuse' perlu seberapa } \\
\text { cepat ditangani }\end{array}$ \\
\hline 7 & $\begin{array}{l}\text { Menurut anda, Isu 'Terorisme' perlu seberapa } \\
\text { cepat ditangani }\end{array}$ \\
\hline
\end{tabular}

dilakukan dengan metode penelitian deskriptif dimana metode penelitian ini didasarkan oleh penelitian yang dilakukan oleh peneliti terdahulu dimana penelitian yang dilakukan adalah dengan menggunakan penelitian deskriptif untuk mengumpulkan data dari responden terpilih yang diteliti berkaitan tentang pengetahuan responden akan nilai moral yang terkandung dalam sebuah novel dalam penelitiannya [18]. Sehingga pada penelitian ini, peneliti akan membahas video game dari sudut pandang dari setiap poin SDG. Dimana penelitian dilakukan dengan melihat playlist dari game play video game Detroit Become Human dan mencatat setiap plot point yang memiliki keterkaitan dengan SDG, kemudian peneliti melakukan perancangan kuesioner dimana kuesioner untuk setiap video yang tedapat dalam playlist dimana setiap kuesioner terdiri dari pertanyaan deskriptif untuk disebarkan kepada responden penelitian mengenai reaksi penonton terhadap isu dunia yang ada dari game play video game yang telah peneliti sediakan setiap harinya. Sebelum proses penyebaran kuesioner utama, peneliti juga merancang kuesioner mengenai permasalahan dunia (Lihat Tabel 1) untuk diuji kepada responden sebagai pre-test sebelum penelitian dimulai yang mana akan diuji kembali setelah semua kuesioner utama telah selesai sehingga peneliti dapat melakukan perbandingan terhadap pandangan responden mengenai permasalahan dunia tersebut sebelum responden terekspos oleh video game dan setelah responden terekspos oleh video dengan menonton game play dari video game yang diberikan.

Penulis akan melakukan analisa pada dua sisi untuk menentukan hasil daripada penelitian yang dilakukan yaitu dengan melakukan perbandingan kondisi responden sebelum dan sesudah terkespos oleh video game dan dengan melihat seberapa efektif video game dapat menyampaikan isu serius dunia pada pengguna dengan melakukan proses kodifikasi dari jawaban deskriptif setiap kuesioner yang dikategorikan dalam tiga kategori yaitu demi kebaikan diri sendiri, orang lain dan kebaikan public

Tabel 2. Hasil Penelitian

\begin{tabular}{clc}
\hline No & \multicolumn{1}{c}{ Isu Dunia } & Perubahan \\
\hline 1 & Isu Rasisme & $25.93 \%$ \\
\hline 2 & Isu Kekerasan pada anak-anak & $22.22 \%$ \\
\hline 3 & Isu Bullying & $29.63 \%$ \\
\hline 4 & Isu Kesehatan mental & $33.33 \%$ \\
\hline 5 & $\begin{array}{l}\text { Isu sosial-ekonomi dan } \\
\text { kesenjangan }\end{array}$ & $59.26 \%$ \\
\hline 6 & Isu drugs abuse & $33.33 \%$ \\
\hline 7 & Isu Terorisme & $14.81 \%$ \\
\hline
\end{tabular}

yang kemudian akan diuji kembali dengan hasil jawaban dari kuesioner post-test.

\section{HASIL DaN PEMbahasaN}

Dari 27 responden yang telah terpapar oleh video game Detroit: Become Human. Pada analisis yang pertama mengenai perbandingan kondisi dari responden sebelum dan setelah terpapar oleh video game, ditemukan perubahan kondisi yang cukup tinggi yaitu terdapat lebih dari $50 \%$ perbedaan pandangan dari kondisi sebelumnya. Perubahan tersebut dapat ditemukan pada perubahan pandangan responden terkait salah satu isu dunia yaitu mengenai isu sosio-ekonomi. Secara umum terdapat perubahan pandangan juga pada isu dunia lainnya namun perubahan yang terjadi tidak terlalu tinggi yaitu hanya mencapai angka 25\%. Terdapat beberapa isu yang sama sekali tidak terjadi perubahan pandangan yaitu terkait isu kekerasan terhadap anak dan terhadap isu terorisme. Pertanyaan terkait isu tersebut 
JURNAL ILMIAH KOMPUTER GRAFIS, Vol.13, No.2, Juli 2020, pp. 1 - 6

p-ISSN : 1979-0414(print) e-ISSN : 2621-6256 (online)

http://journal.stekom.ac.id/index.php/pixel

berkaitan dengan isu dunia yang cukup serius. Misalnya isu terorisme, dari 27 responden hanya terdapat 4 responden yang melaporakan adanya perubahan pandangan yang mana 4 diantaranya menurun. Hal tersebut dapat terjadi dikarenakan hampir semua responden memberikan nilai maksimal sebelum responden terpapar dan setelah responden terpapar video game Detroit Become Human untuk isu terkait terorisme. Berikut adalah hasil analisis mengenai isu dunia yang peneliti lakukan terhadap game Detroit Become Human diantaranya terdiri dari tujuh isu diantaranya isu terkait rasisme, isu terkait kekerasan terhadap anak, isu terkait permasahalan bullying, isu terhadap kesehatan mental, isu terhadap sosio-ekonomi, isu terhadap narkoba dan obat-obatan terlarang dan yang terakhir yaitu isu terkait terorisme (Lihat Tabel 2).

Hasil analisis pada pengujian yang kedua terkait hasil kodifikasi dari jawaban deskriptif oleh responden terhadap video game setiap harinya (Lihat Tabel 3)

Hal ini sangat menarik karena pada video game Detroit Become Human ini menunjukkan nilai terendah untuk petugas hukum sebagai oknum yang tidak bertanggung jawab sebagai peran antagonis yaitu mendapatkan nilai 4.74 bahkan terdapat beberapa responden yang mengungkapkan hasil negatif.

Terkait aspek kebebasan pada video game Detroit Become Human ini membahas kebebasan terkait isu rasisme yang mana dapat ditemukan pada kasus rasisme manusia terhadap robot yaitu mendapatkan nilai 3.63 hal ini membuktikan meskipun isu rasisme mempengaruhi responden dengan nilai $25 \%$ namun karena kasus rasisme dalam video game Detroit Become Human ini berkaitan dengan robot dan bukan manusia sehingga tidak terdapat perubahan yang signifikan.

Penilaian terkait tiga aspek berikutnya yaitu terkait aspek kebaikan terhadap diri sendiri, kebaikan terhadap orang lain, dan juga kebaikan terhadap publik. Pada video game ini simpati yang ditunjukkan oleh responden terhadap aspek kebaikan terhadap diri sendiri dan orang lain sangat jelas (Diri Sendiri: 12.85, Orang Lain: 13.70) namun, simpati terhadap aspek kebaikan publik relatif rendah (2.96). Hal ini diakibatkan karena penggambaran proses revolusi pada robot dalam video game ini menggambarkan otoritas dan publik secara negatif. Hal ini menunjukkan hasil yang kontradiktif dengan hasil penelitian dengan analisis perbandingan kondisi responden sebelum dan setelah terpapar video game dimana pada hasil kodifikasi ini menunjukkan bahwa secara umum membuktikan bahwa video game belum memungkinkan untuk merubah moral responden.

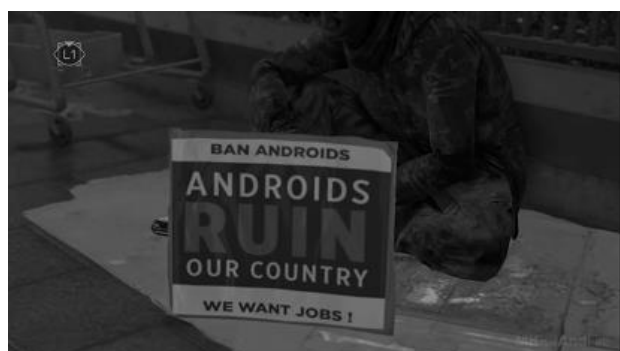

Gambar 2. Isu kemiskinan, pekerjaan yang layak dan pertumbuhan ekonomi serta kota dan komunitas berkelanjutan

Salah satu kondisi yang mengakibatkan situasi tersebut dapat terjadi adalah karena adanya pengaruh waktu. Dimana penelitian yang pertama dipusatkan oleh pandangan moral jangka panjang yang membicarakan isu dunia secara umum sedangkan penelitian yang kedua dipusatkan untuk pandangan moral jangka pendek dikarekan responden diminta untuk memberikan respon deskriptif terhadap video harian yang baru mereka tonton.

Video game Detroit Become Human ini sangat menarik jika dikaitkan dengan Sustainable Development Goals dikarekan banyak sekali isu isu dunia yang dipaparkan dalam video game ini. Terkait tujuan SDG yang pertama yaitu tentang kemiskinan yang berkaitan erat dengan isu kedua dari SDG kelaparan, melalui penggambaran terhadap Kara dan Alice yang melarikan diri dari Todd, pada saat itu mereka tidak menghadapi masalah keuangan

Tabel 3. Hasil Kodifikasi

\begin{tabular}{clc}
\hline No & \multicolumn{1}{c}{ Aspek } & Hasil kodifikasi \\
\hline 1 & Hukum & 4.74 \\
\hline 2 & Kebebasan & 3.63 \\
\hline 3 & Kebaikan diri & 12.85 \\
\hline 4 & Kebaikan orang lain & 13.70 \\
\hline 5 & Kebaikan publik & 2.96 \\
\hline
\end{tabular}

sehingga mereka kelaparan dan tidak memiliki tempat tinggal yang memaksa mereka untuk melakukan hal yang melawan hukum (Lihat Gambar $1)$. 
JURNAL ILMIAH KOMPUTER GRAFIS, Vol.13, No.2, Juli 2020, pp. 1 - 6

p-ISSN : 1979-0414(print)

e-ISSN : 2621-6256 (online)

http://journal.stekom.ac.id/index.php/pixel

- page 1

Pada sisi lain penggambaran terkait kemiskinan juga dapat terlihat pada kondisi lapangan pekerjaan yang diambil alih oleh robot, hal ini juga berkaitan erat dengan tujuan SDG yang ke 8 yaitu mengenai pekerjaan yang layak dan pertumbuhan ekonomi serta tujuan yang ke 11 yaitu mengenai kota dan komunitas berkelanjutan. Hal ini sangat menarik karena

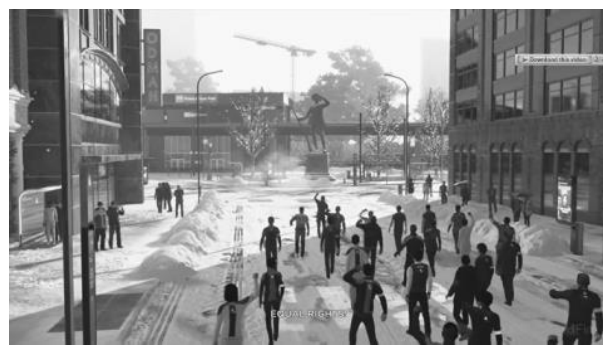

Gambar 5. Penggambaran mengenai perdamaian, keadilan dan kelembagaan serta kemitraan untuk mencapai tujuan

berhubungan dengan isu dunia yang diteliti yaitu mengenai isu sosial ekonomi dan kesenjangan yang telah dibahas mengenai hasil penelitian berdasarkan tabel 1 (Lihat Gambar 2).

Kasus lainnya mengenai kemiskinan juga digambarkan pada kehidupan robot di Jericho yang menunjukkan betapa sulitnya kehidupan mereka isana sehingga banyak robot yang harus dinonaktifkan (Lihat Gambar 3).

Tujuan SDG yaitu tujuan yang ke 3 yaitu kehiduan yang sehat dan sejahtera yang juga dibahas dalam video game ini contohnya pada penggambaran isu kasus Carl, orang tua yang diasuh oleh robot bernama Markus, dimana robot disini menjadi salah satu bentuk untuk mendukung kesejahteraan dan kesehatan Carl (Lihat Gambar 4).

Disini lain pada kasus keluarga Todd, dimana Todd membeli robot Kara untuk mengasuh Alice sehingga kehidupannya dapat menjadi lebih sejahtera dan teratur. Pada sisi lain, juga terdapat penggambaran terhadap tujuan SDG yang ke 16 yaitu mengenai

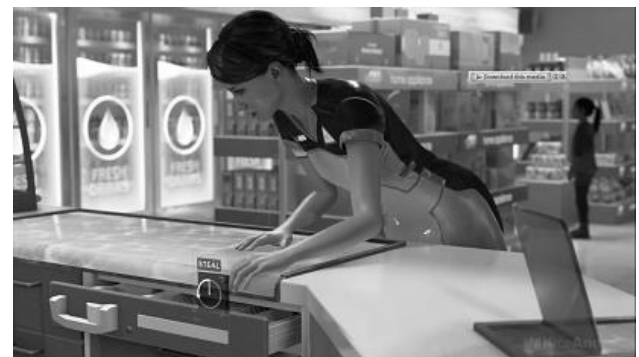

Gambar 1. Isu kemiskinan dan kelaparan perdamaian, keadilan dan kelembagaan yang berkaitan erat dengan tujuan 17 yaitu kemitraan untuk mencapai tujuan dimana pada video game ini menggambarkan kasus penggerakan massa yaitu robot untuk memperjuangkan keadilan dan kedamaian hidup mereka diantara manusia yang dilakukan oleh Markus yang bermitra dengan robot lainnya demi mencapai tujuan keadilan tersebut (Lihat Gambar 5).

Dari Bahasan tersebut dengan terdapatnya cukup banyak konten yang terkait isu yang dibawa oleh SDG didalam video game Detroit Become Human, didukung oleh hasil penelitian dimana perubahan kesadaran pada setiap isu dunia cukup signifikan terjadi pada responden, kami bisa menyatakan bahwa video game, khususnya Detroit Become Human bisa menjadi media edukasi isu dunia seperti SDG.

Berdasarkan penelitian yang telah kami lakukan, dengan adanya video game dengan nilai edukasi seperti Detroit Become Human yang mana banyak mempaparkan tentang isu yang sedang dihadapi oleh dunia saat ini sangat membantu dalam mengedukasi para pemain game. Secara tidak langsung, pemain dapat menyadari akan urgensi dalam menghadapi isu-

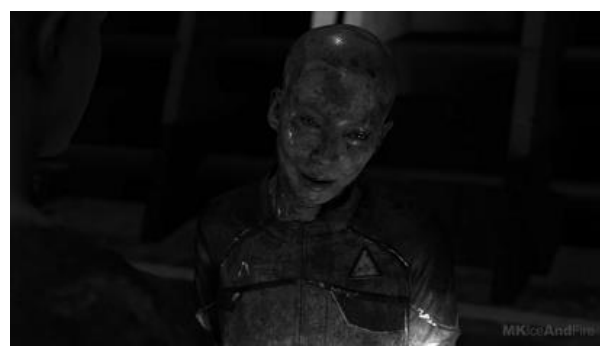

Gambar 3. Penggambaran isu kemiskinan melalui kehidupan robot di Jericho

isu dunia dan mendukung usaha yang dilakukan oleh PBB dalam mewujudkan SDG.

Video game saat ini cukup banyak mengangkat isu terkait kekerasan, dan objektifitas, namun sayangnya tidak banyak video game yang mengangkat isu-isu dunia didalamnya. Hal ini sangat disayangkan karena hasil penelitian yang kami lakukan membuktikan bahwa video game dapat

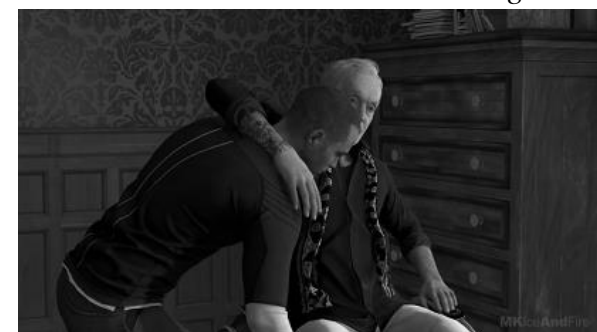

Gambar 4. Penggambaran mengenai dukungan atas isu kesejahteraan dan kesehatan 
JURNAL ILMIAH KOMPUTER GRAFIS, Vol.13, No.2, Juli 2020, pp. 1 - 6

p-ISSN : 1979-0414(print) e-ISSN : 2621-6256 (online)

menjadi media edukasi isu dunia dan video game dapat menjadi salah satu media yang cukup efektif apalagi pada zaman ini yang mana banyak sekali orang-orang bermain video games dari segala rentang usia.

Pengembangan video game pada era ini cukup pesat, dan dengan penelitian yang telah kami lakukan yang telah membuktikan bahwa video game dapat menjadi media edukasi isu dunia, maka pengembangan video game dengan mengangkat tema mengenai isu dunia secara implisit dapat menjadi salah satu alternatif bagi developer game untuk turut campur tangan dalam mengedukasi pemain game sehingga game tidak hanya menjadi sarana hiburan bagi pemainnya.

\section{KESIMPULAN}

Berdasarkan penelitian yang telah kami lakukan dengan tujuan untuk membuktikan efektifitas video game sebagai media edukasi terkait isu dunia menunjukkan hasil yang positif, dimana hal ini membuktikan bahwa video game cukup berpotensi untuk menjadi media edukasi terhadap isu dunia. Pengaruh yang diberikan relatif rendah terhadap aspek tertentu namun demikian, respon terhadap penggunaan video game sebagai media edukasi isu dunia yang dilaporkan menunjukkan respon yang positif sesuai dengan penelitian terdahulu [14], [15], [16], [17]. Video game terbukti dapat memberi dampak kepada penggunanya terhadap pandangan mengenai isu dunia dengan rentang waktu jangka panjang namun belum menunjukkan dampak yang signifikan terhadap persepsi isu dunia dalam jangka pendek. Laporan yang didapat dari hasil penelitian yang kami lakukan dapat diindikasikan bahwa tanggapan terhadap video game serta pengaruhnya menunjukkan respon yang positif, namun untuk meninjau video game sebagai media edukasi terhadap isu dunia secara umum masih perlu dilakukan pengkajian lebih lanjut. Kuantifikasi mengenai bagaimana video game dapat menjadi media edukasi isu dunia masih perlu dielaborasi dengan pengkajian mendatang.

\section{UCAPAN TERIMA KASIH}

Penulis berterimakasih kepada Rektor serta Universitas Internasional Batam. Penulis juga berterima kasih kepada rekan penulis, Edi Hendry yang turut serta membantu penulis dalam melaksanakan penelitian. Dan yang terakhir, penulis sangat berterimakasih kepada seluruh responden responden yang tidak dapat penulis sebut satu persatu yang telah bersedia untuk memberikan laporan deskriptif setiap harinya untuk mendukung penelitian ini selama 22 hari.

\section{DAFTar Pustaka}

[1] J. S. Salvia, A. L., Leal Filho, W., Brandli, L. L., \& Griebeler, "Assessing Research Trends Related to Sustainable Development Goals : Local and Global Issues," J. Clean. Prod., vol. 208, no. 1, pp. 841-849, 2019.

[2] W. L. Filho, S. K. Tripathi, J. B. S. O. D. A. Guerra, R. Giné-Garriga, V. Orlovic Lovren, and J. Willats, "Using the Sustainable Development Goals Towards a Better Understanding of Sustainability Challenges," Int. J. Sustain. Dev. World Ecol., vol. 26, no. 2, pp. 179-190, 2019.

[3] S. L. Schmidt, Video Games, Technology, and Sport: The Future Is Interactive, Immersive, and Adaptive. 2020.

[4] N. Shaykhislamov, "Main Directions and Interactive Methods of Student Speech Growth in Uzbek Language Classes," Eur. J. Res., vol. 8, no. 7, pp. 115-120, 2020.

[5] K. Tilvawala, M. Myers, and D. Sundaram, "Designing Serious Games for a Sustainable World," Int. Conf. Inf. Resour. Manag., p. 25, 2019.

[6] M. F. Perreault, G. P. Perreault, J. Jenkins, and A. Morrison, "Depictions of Female Protagonists in Digital Games: A Narrative Analysis of 2013 DICE Award-Winning Digital Games," Games Cult., vol. 13, no. 8, pp. 843-860, 2018.

[7] S. Piittinen, "Injustice in the Ruins and a Disordered Post-Apocalypse: Gothic Ideology in the Digital Game World of Fallout 3," Stud. Gothic Fict., vol. 6, no. 2, pp. 40-50, 2020.

[8] T.-S. Neset, L. Andersson, O. Uhrqvist, and C. Navarra, "Serious Gaming for Climate Adaptation-Assessing the Potential and Challenges of a Digital Serious Game for Urban Climate Adaptation," Sustainability, vol. 12 , no. 5 , p. $1789,2020$.

[9] B. de Andrade, A. Poplin, and Í. S. de Sena, "Minecraft as a tool for engaging children in urban planning: A Case study in Tirol Town, Brazil," ISPRS Int. J. Geo-Information, vol. 9, no. 3, p. 170, 2020.

[10] N. Tancred, N. Vickery, P. Wyeth, and S. Turkay, "Player choices, game endings and the design of moral dilemmas in games," CHI 
JURNAL ILMIAH KOMPUTER GRAFIS, Vol.13, No.2, Juli 2020, pp. 1 - 6

p-ISSN : 1979-0414(print)

e-ISSN : 2621-6256 (online)

http://journal.stekom.ac.id/index.php/pixel

page 1

Play 2018 - Proc. 2018 Annu. Symp. Comput. Interact. Play Companion Ext. Abstr., no. October, pp. 627-636, 2018.

[11] E. Holl, "Rise of the machines - Moral decisions in Detroit Become Human," vol. 1, no. 1, pp. 1-11, 2019.

[12] S. A. Pramuditya, Wahyudin, E. Nurlaelah, and M. S. Noto, "Parent's Perspective on Educational Games: Phenomenography Study in Indonesia," J. Xi'an Univ. Archit. Technol., vol. 7, no. 2, pp. 861-874, 2020.

[13] Y. Hartanto, T. Sanjaya, and T. Windranata, "Pengaruh Game Berbasis Coding Terhadap Keberlanjutan Minat Belajar Programming Siswa di Batam, Indonesia," J. Teknol. Inf., vol. 6, no. 1, pp. 19-27, 2020.

[14] T. Wibowo, "Studi Inisial Potensi Video Game Sebagai Media Belajar Untuk Moral," J. Animat. Games Stud., vol. 6, no. 2, pp. 129-140, 2020.

[15] G. H. Iten, J. A. Bopp, C. Steiner, K. Opwis, and E. D. Mekler, "Does a Prosocial Decision in Video Games Lead to Increased Prosocial Real-Life Behavior? The Impact of Reward and Reasoning," Comput. Human Behav., vol. 89, no. 1, pp. 163-172, 2018.

[16] J. Katsarov, M. Christen, R. Mauerhofer, D. Schmocker, and C. Tanner, "Training Moral Sensitivity Through Video Games: A Review of Suitable Game Mechanisms," Games Cult., vol. 14, no. 4, pp. 344-366, 2019.

[17] J.-W. Yang, S.-J. Gang, and B.-C. Bae, "A Study of the Effect of Character Perspectives on the Player's Moral Decision in Interactive Story," J. Korea Game Soc., vol. 16, no. 6, pp. 111-120, 2016.

[18] S. P. H. K. . D. R. S. . E. Winarsih, "Nilai Moral Dalam Novel 'Rumah Pucat' Karya E. L. Hadiansyah," Widyabastra J. Ilm. Pembelajaran Bhs. dan Sastra Indones., vol. 7, no. 1, pp. 37-44, 2019. 